\title{
PENGARUH PENGGUNAAN MODEL ADVANCE ORGANIZER TERHADAP HASIL BELAJAR MATERI PEMBELAJARAN EKOSISTEM SISWA KELAS VII SMPN 35 BATAM
}

\section{THE INFLUENCE OF USING ADVANCE ORGANIZER MODEL TOWARD ECOSYSTEM LEARNING OUTCOMES OF GRADE VII STUDENTS AT SMPN 35 BATAM}

\author{
Zulpikar Zulfikar ${ }^{1}$, Dahrul Aman Harahap $*^{2}$, Fauziah Syamsi ${ }^{3}$ \\ ${ }^{1,2,3}$ Program Studi Pendidikan Biologi, FKIP, Universitas Riau Kepulauan, Batam \\ *Koresponden: amanhrp@yahoo.com
}

\begin{abstract}
Abstrak
Penelitian yang dilakukan di SMPN 35 Batam bertujuan untuk mengetahui pengaruh model Advance Organizer pada hasil belajar siswa kelas VII dalam materi Ekosistem. Penelitian ini merupakan penelitian eksperimen memanfaatkan seluruh populasi siswa kelas VII dimana sampel pengamatan kelas VII.6 sebagai kelas kontrol (X1) dan kelas VII.4 sebagai kelas eksperimen (X2) dengan mengambil sampel secara acak sederhana (Simple Random Sampling). Diperoleh data pengamatan menggunakan instrumen hasil belajar pilihan berganda. Analisis hasil data dilakukan dengan menggunakan teknik statistik inferensial Uji t pada tingkat signifikansi ini $\alpha=0,05$ dengan hasil sajian adalah $\mathrm{t}$ hitung $4.46>\mathrm{t}$ tabel 1,67. Hasil ini menyatakan bahwa bahwa hipotesis awal $\left(\mathrm{H}_{0}\right)$ ditolak dan menerima ada beda nyata $\left(\mathrm{H}_{\mathrm{i}}\right)$ artinya bahwa model pembelajaran menggunakan Advance organizer menunjukkan beda nyata dalam hasil belajar materi ekosistim.
\end{abstract}

Kata Kunci: Model Advance Organizer; Hasil belajar; Ekosistem.

\begin{abstract}
This research was conducted at SMPN 35 Batam which aims to determine the effect of Advance Organizer model toward students' learning outcomes for Ecosystem learning material. This study was an experimental study utilizing the entire population of students grade VII in which grade VII.6 as the control class (X1) and class VII.4 as experiment class (X2) which was taking by simple random sample. Observational data obtained using multiple choice test as instruments of learning outcomes. Data analysis was done by using the $t$ test inferential statistical techniques at $\alpha=0.05$ level with the results $t$ count $(4.46)>t_{\text {table }}$ (1.67). These results states that the initial hypothesis $\left(H_{0}\right)$ is rejected and no significant difference $\left(H_{i}\right)$ is received, it means that the learning model using Advance organizer shows the significant difference toward ecosystems material learning outcomes.
\end{abstract}

Keywords: Advance Organizer Model, Learning Outcomes; Ecosystem.

\section{PENDAHULUAN}

Keberhasilan proses belajar mengajar di sekolah sangat dipengaruhi oleh keberhasilan proses belajar mengajar di dalam kelas, berhasil tidaknya proses belajar di kelas ditentukan oleh kemampuan guru dalam menyampaikan pelajaran. Untuk itu dalam proses pembelajaran guru perlu menciptakan kondisi belajar yang bisa membuat siswa menjadi aktif, kreatif dan inovatif dalam belajar. Seorang guru dituntut 
kemampuannya untuk menumbuhkan minat dan motivasi siswa agar dapat menguasai apa yang telah dipelajarinya sehingga dapat meningkatkan hasil belajar siswa. Proses pembelajaran biologi tidak terlepas dari kurikulum yang telah ditetapkan sebagai acuan, dalam hal ini kurikulum yang ditetapkan adalah kurikulum tingkat satuan pendidikan atau lebih dikenal KTSP.

Berdasarkan pengamatan serta informasi yang diperoleh selama melaksanakan Program PPL (Praktek Pengalaman Lapangan), hasil belajar siswa yang diperoleh belum mencapai hasil yang memuaskan. Menurut data saat observasi langsung pada guru mata pelajaran Biologi kelas VII SMP Negeri 35 Batam terlihat bahwa rata-rata nilai ujian tengah semester biologi kelas VII belum memuaskan, karena ada nilai di bawah Kriteria Ketuntasan Minimal (KKM) yaitu 68 yang ditetapkan sekolah.

Salah satu bentuk tipe dari pembelajaran yang dapat diterapkan untuk meningkatkan keaktifan siswa dalam pembelajaran biologi adalah dengan menggunakan model advance organizer. Menurut Corkill dalam Eggen dan Kauchak (2012) Advance Organizer adalah pernyataan lisan atau tertulis pada awal pembelajaran yang meringkaskan dan menstrukturkan materi baru serta mengaitkannya dengan pengetahuan latar belakang yang dimiliki siswa. Pengunaan model advance organizer diharapkan dapat mengarahkan siswa ke materi yang akan dipelajari sehingga siswa dapat mengingat kembali informasi yang berhubungan dan membantu siswa menanamkan pengetahuan. Penelitian ini bertujuan untuk membuktikan pengaruh penggunaan model advance organizer terhadap hasil belajar pada pembelajaran ekosistem siswa SMPN 35 Batam.

\section{METODOLOGI}

Penelitian ini laksanakan pada bulan April -Mei 2013 pada semester genap di SMP Negeri 35 Batam tahun ajaran 2012/2013. Metode menggunakan metode eksperimen semu (Quasi Experiment). Terdiri dari 2 (dua) variabel yaitu : Variabel bebas (Independen) merupakan variabel yang mempengaruhi atau yang menjadi sebab perubahannya atau timbulnya variabel terikat (dependen). Sugiyono (2012). Dalam penelitian ini yang menjadi variabel bebas (independen) adalah model advance organizer (X) dan Variabel terikat (Dependen) merupakan variabel yang dipengaruhi atau yang menjadi akibat, karena yang menjadi variabel bebas (independen) adalah hasil 
belajar siswa (Y). Rancangan penelitian dengan pendekatan Randomized Control Group Posttest Only design. Dalam penelitian ini peneliti mengelompokkan sampel menjadi dua kelas, yaitu kelompok kelas eksperimen dan kelompok kelas kontrol diberi pos-tes pada akhir proses pembelajaran. Teknik pengambilan sampel dalam penelitian ini diambil dengan menggunakan teknik random sampling, dengan jumlah sampel penelitian sebanyak 30 siswa pada kelas eksperimen maupun kelas kontrol.

Kalibrasi instrumen tes untuk mendapatkan karakteristik tes yang baik dengan cara memvaliditas dan mereliabilitas tes tersebut. Validitas tes dilakukan dengan cara validitas internal (validitas konten dan kontruksi) dikonsultasikan dengan tenaga ahli sebanyak 3 orang. Validitas secara empiris mengunakan product moment dengan tujuan setiap butir soal memiliki kesahihan secara empirik. Sedangan reliabilitas tes dilakukan dengan perhitungan koefisien reliabilitas mengunakan metode KR-20 (Kuder Ricardson-20) dengan tujuan setiap butir soal yang disusun memiliki keterandalan secara empirik.

Data penelitian dianalisis dengan statistik deskriptif dan inferensial. Analisis statistik deskriptif secara umum digunakan untuk menyajikan data dalam yang divisualisasikan dalam bentuk histogram pada kelas eksperimen maupun kelas kontrol. Uji normalitas data mengunakan uji liliefors dan uji homogenitas mengunakan uji chikuadrat. Pengujian hipotesis dilakukan dengan mengunakan uji t satu pihak dengan rumus separated varians untuk membuktikan pengaruh model advance organizer.

\section{PEMBAHASAN}

Berdasarkan dari hasil analisis dari data tes secara deskriptif didapat rata-rata hasil belajar biologi siswa pada kelas eksperimen 77.4 dan pada kelas kontrol 68.4. berarti hasil belajar biologi siswa dengan menggunakan model advance organizer pada pembelajaran ekosistem lebih tinggi daripada dengan menggunakan pembelajaran konvensional. Model advance organizer menjadikan siswa termotivasi untuk belajar biologi dengan pokok bahasan ekosistem bisa dihubungkan dengan kegiatan mereka sehari-hari, dengan mereka termotivasi semangat mereka untuk belajar akan timbul jadi pembelajaran menjadi semakin menarik dan siswa menjadi aktif. Model advance organizer mempunyai kelebihan dalam memperoleh penjelasan terlebih dahulu di awal pembelajaran mengenai apa yang akan dipelajari. Sehingga siswa akan lebih siap untuk 
menerima materi pembelajaran. Seperti terlihat pada histogram kelas eksperimen pada Gambar 1.

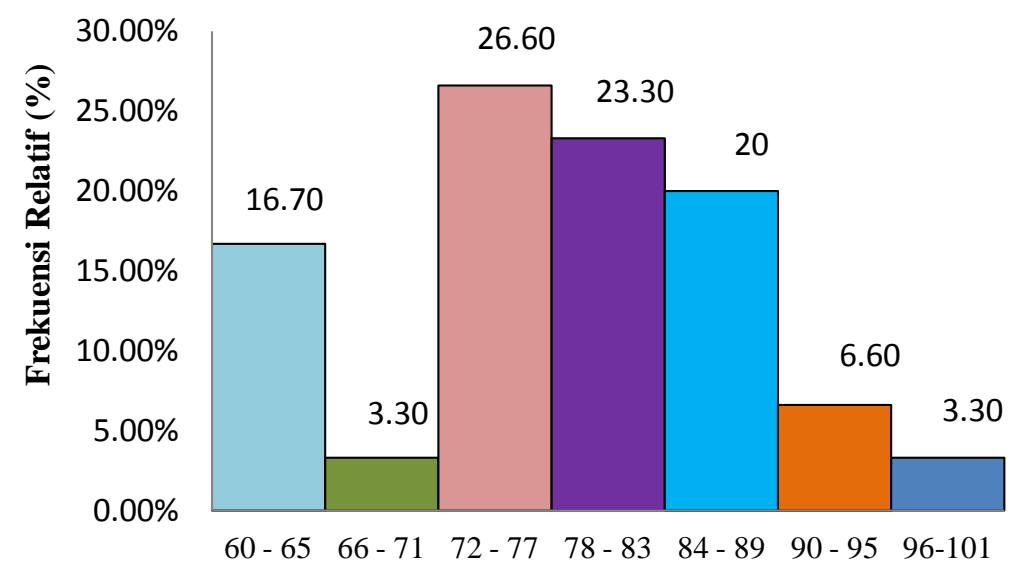

Interval Kelas

Gambar 1. Hasil Belajar Biologi siswa Kelas Eksperimen

Dari Gambar Histogram 1 dapat terlihat bahwa dari 30 orang siswa sebagai sampel penelitian pada kelas eksperimen nilai angka hasil belajar untuk setiap kelas interval bervariasi. dimana nilai siswa lebih dominan dikisaran interval kelas 60-65 dengan frekuensi relatif 16.70, interval kelas 66-71 dan 96-101 dengan frekuensi relatif berjumlah 3.30, interval kelas 72-77 dengan frekuensi relatif berjumlah 26.60, interval kelas 78-83 dengan nilai frekuensi relatif 23.30, dan interval kelas 84-89 dengan jumlah nilai frekuensi relatif sebesar 20, dan interval kelas 90-95 dengan jumlah nilai frekuensi relatif sebesar 6.60. sedangkan hasil belajar kelas kontrol dapat dilihat pada Gambar 2.

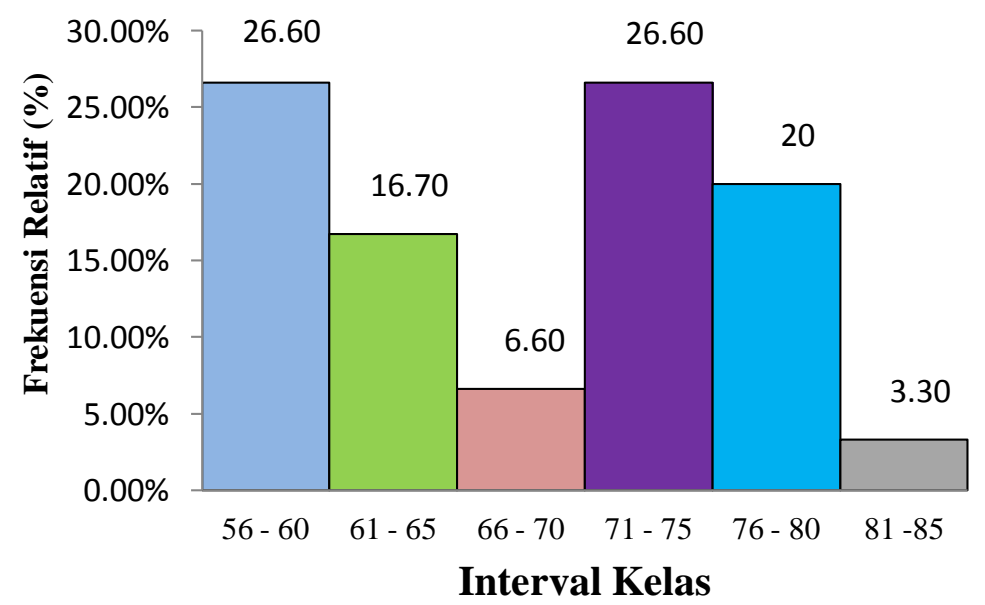

Gambar 2. Hasil Belajar Biologi Siswa Kelas Kontrol 
Dari Gambar 2 dapat terlihat nilai dari 30 orang siswa sebagai sampel penelitian pada kelas kontrol bervariasi, dimana nilai siswa lebih dominan dikisaran interval kelas 56-60 dan 71-75 dengan frekuensi relatif 26.60, interval kelas 61-65 dengan frekuensi relatif berjumlah 16.70, interval kelas 66-70 dengan frekuensi relatif berjumlah 6.60, interval kelas 76-80 dengan nilai frekuensi relatif 20, dan interval kelas 81-85 dengan jumlah nilai frekuensi relatif sebesar 3.30. Dari data tersebut peneliti dapat melihat perbandingan nilai antara kelas eksperimen yang mendapatkan perlakuan dengan menggunakan model advance organizer dan kelas kontrol tanpa ada perlakuan yaitu dengan menggunakan pembelajaran konvensional. Untuk lebih jelas dapat di lihat pada Tabel 1.

Tabel 1. Nilai Rata-rata Kelas Eksperimen dan Kontrol

\begin{tabular}{ccc}
\hline Kelas & $\mathbf{N}$ & $\overline{\boldsymbol{X}}$ \\
\hline Eksperimen & 30 & 77.4 \\
Kontrol & 30 & 68.4 \\
\hline
\end{tabular}

Uji normalitas dilakukan dengan menggunakan uji Liliefors pada taraf signifikansi $(\alpha)=0,05$. Uji Normalitas pada Kelas Eksperimen diperoleh $\mathrm{X}^{2}$ hitung yaitu sebesar $7.13<\mathrm{X}_{\text {tabel }}^{2}$ yaitu sebesar 11.070, hal tersebut dapat diartikan bahwa data hasil belajar biologi siswa dengan penggunaan model advance organizer (variabel X) berdistribusi normal. Sedangkan Uji Normalitas pada Kelas kontrol diperolehX ${ }^{2}{ }_{\text {hitung }}$ yaitu sebesar $9.87<\mathrm{X}^{2}$ tabel yaitu sebesar 11.070, hal tersebut dapat diartikan bahwa data hasil belajar biologi siswa tanpa menggunakan model advance organizer (variabel Y) berdistribusi normal

Setelah prasyarat normalitas terpenuhi, selanjutnya dilakukan pengujian homogenitas data hasil penelitian. Pengujian homogenitas dilakukan untuk menganalisis data untuk setiap kelompok perlakuan penelitian berasal dari populasi yang sama atau homogen. Uji homogenitas populasi dilakukan dengan menggunakan uji chi-kuadrat pada taraf signifikan $(\alpha)=0,05$. Dari hasil homogenitas didapatkan $F_{\text {hitung }}$ sebesar 1.48 kemudian dibandingkan dengan nilai $F_{\text {tabel, }}$ untuk $\alpha=0.005$ maka harga $\mathrm{F}_{\text {tabel }}=1,87$ ( harga dk pembilang 29 dan dk penyebut 29) sesuai dengan lampiran . Oleh karena $F_{\text {hitung }}<F_{\text {tabel }}$ dimana 1,48 $<1,87$ maka dapat disimpulkan bahwa kedua kelompok data tersebut memiliki varians yang Homogen 
Uji Hipotesis dilakukan dengan teknik analisis statistik inferensial bertujuan mengkaji, menaksir dan mengambil kesimpulan berdasarkan data yang diperoleh dari sampel untuk mengambarkan karakteristik atau ciri dari suatu populasi. Dari hasil perhitungan dengan uji-t maka didapat harga $t_{\text {hitung }} 4.46$ dan para taraf nyata 0.05 didapat harga $t_{\text {tabel }} 1.67$ dengan derajat kebebasan 58. Karena $t_{\text {hitung }}>t_{\text {tabel }}$ berarti $t_{\text {hitung }}$ berada di luar daerah penerimaan $\mathrm{H}_{0}$, oleh karena itu dapat dikatakan bahwa hipotesis diterima. Dapat disimpulkan bahwa terdapat pengaruh yang berarti hasil belajar siswa antara kelas eksperimen yang mendapat perlakuan dengan menggunakan model advance organizer dibandingkan dengan kelas kontrol yang menggunakan pembelajaran konvensional.

Nilai hasil belajar biologi siswa dengan menggunakan model advance organizer pada pembelajaran ekosistem lebih tinggi daripada dengan menggunakan pembelajaran konvensional. Hal ini disebabkan adanya penggunaan model advance organizer kepada siswa di kelas eksperimen. Model advance organizer menjadikan siswa termotivasi untuk belajar biologi pokok bahasan ekosistem bisa dihubungkan dengan kegiatan mereka sehari-hari dan umumnya tampak siswa akan lebih siap untuk menerima materi pembelajaran karena adanya penjelasan pendahuluan.

Menurut Supriyanti (2004) dalam Susmidila (2009) bahwa penggunaan model advance organizer dapat meningkatkan aktivitas guru-siswa dalam proses pembelajaran, serta hasil belajar siswa dalam pembelajaran dimana siswa berkesempatan untuk mengembangkan pola pikirnya. Selain itu menurut Harley dan Davis dalam Susmidila (2009) ada beberapa penelitian yang mengkaji tentang model advance organizer, menyatakan bahwa model advance organizer terbukti secara signifikan memudahkan belajar peserta didik. Selain itu pada siswa yang mempunyai kemampuan rendah penggunaan advance organizer dapat meningkatkan pemahaman siswa dalam proses pembelajaran.

Sementara di kelas kontrol pembelajaran lebih didominasi oleh guru yang membuat siswa merasa bosan dan jenuh sehingga siswa menjadi diam dan kurang aktif, justru dengan keadaan seperti ini membuat siswa memperoleh nilai yang kurang memuaskan.Dari uji-t pada taraf nyata 0.05 dan derajat kebebasan 58 diperoleh harga $t_{\text {hitung }} 4.46$ dan harga $t_{\text {tabel }}$ 1.67. dengan demikian $t_{\text {hitung }}>t_{\text {tabel }}$ yang berarti bahwa 
terdapat pengaruh penggunaan model advance organizer pada pembelajaran ekosistem terhadap hasil belajar siswa SMPN 35 Batam.

Dalam model advance organizer guru berperan sebagai pengelola materi pembelajaran dan cenderung sepihak, sedangkan menggunakan model advance organizer terdapat hubungan timbal balik antara siswa dengan siswa dan siswa dengan guru, hal ini dapat terlihat dimana siswa bisa diskusi dengan temannya, atau apabila guru meminta dibuat perkelompok, siswa bisa berdiskusi dengan teman kelompoknya dan mempersentasikan di depan kelas. Siswa juga dapat melakukan tanya jawab dengan guru begitupun sebaliknya, guru dapat menghubungkan pengalaman-pengalaman siswa dengan materi. Menurut Ausubel (1968) dalam Joyce, Weil, Calhoum (2009) organizer yang paling efektif adalah organizer-i yang menggunakan konsep-konsep, ketentuanketentuan, dan rancangan-rancangan yang sudah akrab dengan siswa seperti ilustrasiilustrasi dan analogi-analogi yang sesuai.

Dengan organizer kemampuan siswa untuk berimajinasi tentang materi yang baru membuat mereka bertanya-tanya, sehingga siswa menjadi aktif dan kritis karena sebelum ke materi yang inti mereka terlebih dahulu disajikan dengan materi-materi yang ringan, jadi siswa merasa senang, tidak mudah jenuh dan bosan sehingga membuat mereka menjadi malas untuk belajar. Penggunaan model advance organizer akan berdampak positif terhadap hasil belajar siswa khususnya pada pembelajaran ekosistem. Secara keseluruhan ahsil penelitian menunjukan bahwa terdapat pengaruh positif pengunaan model advance organizer terhadap hasil belajar pada pembelajaran dengan subjek materi ekosistem.

\section{KESIMPULAN}

Berdasarkan hasil penelitian ini diperoleh kesimpulan bahwa hasil belajar biologi siswa di kelas eksperimen dengan menggunakan model advance organizer sudah lebih baik dibandingkan kelas kontrol. Nilai rata-rata 77.4 untuk kelas eksperimen lebih tinggi dibandingakan nilai hasil belajar di kelas kontrol dengan nilai rata-rata 68.4. Uji-t maka didapat harga $t_{\text {hitung }} 4.46>t_{\text {tabel }} 1.67$ tolak $\mathrm{H}_{0}$ dan terima $\mathrm{H}_{\mathrm{a}}$ berarti penggunaan model advance organizer dapat memberikan pengaruh positif untuk meningkatkan hasil belajar biologi siswa khususnya pada pembelajaran ekosistem. 


\section{DAFTAR PUSTAKA}

Eggen, P dan Kauchak, D. 2012. Strategi dan model pembelajaran. PT Indeks. Jakarta.

Joyce B, Weil M dan Calhoun E. 2011. Model of Teaching. Pustaka pelajar, Yogyakarta.

Sugiyono. 2011. Statistika untuk Penelitian. Alfabeta, Bandung.

Susmidila. 2009. Pengaruh Penerapan Model Pembelajaran Advance Organizer Terhadap Hasil belajar Biologi Siswa Kelas X SMA Negeri I Muaro Jambi [skripsi]. Universitas Jambi Fakultas Keguruan dan Ilmu Pendidikan, Jambi. 